\title{
Using Insulation in China's Buildings: Potential for Significant Energy Savings and Carbon Emission Reductions
}

\author{
Guoliang Liu', Hans Liu ${ }^{2}$ \\ ${ }^{1}$ Institute of Applied Forest Ecology, Chinese Academy of Science, Shenyang, China; ${ }^{2}$ The Biomedical Research Centre, University \\ of British Columbia, Vancouver, Canada. \\ Email: guoliangliu@hotmail.com
}

Received September $29^{\text {th }}$, 2011; revised October 30 $0^{\text {th }}$ 2011; accepted November $8^{\text {th }}, 2011$.

\begin{abstract}
Most old residential and commercial buildings in China are not insulated or not to new standards. This is true even in regions with very cold winters or regions with very hot summers. The insulation in new buildings is very poor relative to North American standards. However, insulating the exterior walls, attic roofs, and foundation walls to new standards of buildings in China would reduce the need for heating and air conditioning, and thus would save roughly 200 million tons of coal each year. This in turn would lead to a reduction in $\mathrm{CO}_{2}$ emissions of about 510 million tons per year, which is equal to about 8.4\% of China's total carbon emissions in 2006. The use of insulation in buildings will help homeowners save money, help China save energy and help the environment all at the same time. Insulation will provide a continued payback to the homeowner, not only in dollars and cents, but also by providing a more enjoyable and comfortable living environment for many years.
\end{abstract}

Keywords: China Building Insulation, Air Pollution, Energy and Coal Saving

\section{Introduction}

China burns about 6 million tons of coal every day [1]. According to the World Bank, of the world's top 20 cities with the worst air, 16 are in China [1]. According to Chinese government sources, about one-fifth of urban Chinese breathe heavily polluted air. Many Chinese cities smell like high-sulfur coal and leaded gasoline in the winter. Of the 340 Chinese cities that are monitored for pollution, only one-third meet China's own standards [1]. Coal is the number one source of air pollution in China [1]. "The pollution is worst during the winter," said Ji Youping, a former coal miner who now works with a local environmental protection agency. "Datong gets very black. Even during the daytime, people drive with their lights on". Pollution is a major public health concern of the government. The Asian Development Bank says it is financing pollution control programs in Shanxi because the number of people suffering from lung cancer and other respiratory diseases in the province has soared in the past 20 years [2].

China obtains $80 \%$ of its electricity and $70 \%$ of its total energy from coal, much of which is high-sulfur coal.
The sulfur dioxide produced in coal combustion poses an immediate threat to the health of China's citizens, and contributes to about 400,000 premature deaths a year [2]. It also causes acid rain that poisons lakes, rivers, forests, and crops [2]. During winter, emissions from coal-fired central heating facilities are the primary cause of the serious air pollution that is prevalent in northern China's cities. However, due to the major cost advantage of coal, and to a lack of alternatives, coal is expected to remain the dominant fuel for central heating systems in China for the foreseeable future [3].

Officially, residential and commercial energy use account for $19 \%$ of China's total consumption. This measure, though, omits many commercial and residential buildings that belong to units that are categorized under the industrial, agricultural, construction or other sectors of the economy. Chinese academics estimate that the buildings sector actually accounts for $23 \%$ of total energy use and will exceed $30 \%$ by 2010 [4].

Roughly half of China's population lives in northern regions where temperatures fall below $10^{\circ} \mathrm{C}$ for more than 90 days of the year. In terms of energy per square 
meter of living space, air conditioning uses more energy in areas with hot climates, and heating uses more energy in areas with cold climates. The total energy required for air conditioning and heating combined is the most per square meter in regions with very cold winters and in regions with very hot summers [5]. In regions with only a moderate difference between summer and winter climates, such as in Beijing, the energy required for air conditioning is about the same as that required for heating [5].

China currently consumes about 200 million tons of raw coal per year for space heating of urban, residential, and commercial buildings in its cold and severely cold regions [5]. The amount of energy used for air conditioning is estimated to be about the same as for space heating [5], so China currently consumes about 400 million tons of raw coal per year for the purposes of space heating and air conditioning combined.

Energy use per unit floor area in China is at least double that of buildings in similar cold climates in Western Europe or North America [5], yet far lower levels of comfort are achieved, largely because insulation is not widely used in China's buildings. In Canada, detailed building codes have been in place for decades, and all buildings in all regions are required to be insulated to a certain standard. In Canada, fiberglass is the most common insulation material.

The cost of insulating with fiberglass is very low, even when the framing lumber, vapor barrier, and drywall components are included. The space waste associated with the installation of insulation is very low because only the exterior walls and roof need to be insulated. All electrical wires, network cables, vacuum ducts, ventilation ducts, and telephone lines can easily be installed inside the wall, i.e., between the outer and inner walls, with no need to alter the concrete walls or foundation.

The consumption of heating energy is starting to be metered in many of China's cities, which is causing residents to pay more attention to their heating bills. The use of insulation in buildings will help homeowners save money and help the environment all at the same time. Insulation will provide a continued payback to the homeowner, not only in dollars and cents, but also by providing a more enjoyable and comfortable living environment for many years, and by reducing greenhouse gases and air pollution.

The purpose of this paper is to discuss the effectiveness of installing insulation in buildings in China in terms of saving energy and in terms of reducing carbon emissions by reducing coal consumption. We compared the energy required to maintain the same temperature conditions for insulated and non-insulated buildings in China, based on the research presented in the US Department of Energy's report "Insulation Comparison De- monstration” [6], and we calculated the energy savings and carbon emission reductions associated with implementing the use of insulation.

\section{Effectiveness of Insulation}

Canada's detailed building codes require that the exterior walls, attic roofs, and foundation walls of buildings in all regions be insulated to a certain standard. Fiberglass is the most common insulation material installed inside of concrete walls in Canada. Most old residential and commercial buildings in China, even in the severe weather regions where the winter is cold and the summer is hot, are not insulated. The newer buildings in China are insulated using Styrofoam that is installed outside of the concrete walls. Styrofoam is difficult to install, and the effectiveness of Styrofoam insulation is low, especially after a few of years of moisture building up between the Styrofoam and the concrete wall. Most Styrofoam is not fire resistant, and if a fire does start in a building it facilitates the spread.

Unlike Canada and the United States, China has no clear standards for measuring insulation effectiveness. Every city or region of Canada has a detailed building code that includes clear insulation standards as measured by R-value. ${ }^{1}$ The use of insulation material and technologies has to be standardized in China in order to avoid the mistakes associated with the application of Styrofoam. Much can be learned from countries that have established standards for using insulation, especially fibreglass in buildings.

According to a report by the US Department of Energy [3], a building with fiberglass insulation in the mild region can reduce its energy use by 50\% compared with an uninsulated building. Accordingly, China could reduce its annual coal consumption by about 200 million tons by introducing the use of insulation to Canadian standards in buildings. A calculation that considers the population, the average living space per person, and the space heating energy required per square meter [2,6] reveals that coal consumption would be reduced by 6 million tons per year in Harbin city alone, by 7 million tons per year in Shenyang city alone, and by 15 million tons per year in Beijing city alone, simply by insulating buildings to Canadian standards. According to the basic combustion reaction, $\mathrm{C}+\mathrm{O}_{2}$ to $\mathrm{CO}_{2}+\mathrm{H}_{2} \mathrm{O}$, an incomplete combustion will yield $\mathrm{CO}$ instead of $\mathrm{CO}_{2}$. But, assuming the coal is between $46 \%$ and $98 \%$ carbon, burning 1 ton of coal will

\footnotetext{
${ }^{1} \mathrm{R}$-value is a measure of thermal resistance used in the building and construction industry. Under uniform conditions it is the ratio of the temperature difference across an insulator and the heat flow per unit area. The typical per-inch R-values for building insulation materials are R40 for vacuum-insulated panels, R3.7 for fiberglass, R2.5 for wood panels, and R0.08 for poured concrete. i.e., 1 inch of fiberglass insulation is as effective as 46 inches $(3.7 / 0.08=46)$ of poured concrete [6].
} 
generate 1543 to $3560 \mathrm{~kg}$ of $\mathrm{CO}_{2}$. On average, a 200 million ton reduction in coal for the purposes of heating and air conditioning for the whole of China will mean an overall reduction of 510 million tons of $\mathrm{CO}_{2}$ emissions each year.

Implementing the use of insulation to Canadian standards in China's buildings would reduce annual $\mathrm{CO}_{2}$ emissions by 15 million tons in Harbin alone, by 18 million tons in Shenyang alone, and by 38 million tons in Beijing alone. China's population in 2009 was 1300 million [7], and its per-capita carbon dioxide emissions were 4.65 tons [1], for a total of 6045 million tons of $\mathrm{CO}_{2}$ emissions per year. Therefore, a 510 million ton reduction per year in $\mathrm{CO}_{2}$ emissions as a result of reducing the need for heating and cooling would be equal to about $8.5 \%$ of China's 2006 total $\mathrm{CO}_{2}$ emissions $(510 / 6045=$ $8.5 \%)$.

As per the results of the US Department of Energy's study (Table 1) [6], and based on China's housing development from 2008 to 2010 [7], theoretically China could reduce its annual coal consumption for the purposes of heating and cooling from the current 400 million tons per year to 200 million tons per year by introducing the use of insulation in buildings.

The installation of insulation in buildings requires only a one-time investment on the part of the builder or owner, yet the positive effects on the environment are long term. A one-time insulation investment will provide a 50-year payback. China would save a total of 10,000 million tons of coal during the next 50 years if Canadian standard insulation was introduced to China's buildings today (50 years $\times 200$ million tons per year). At the same time, 25 500 million tons of reduced $\mathrm{CO}_{2}$ emissions would be achieved (50 years $\times 510$ millions tons of $\mathrm{CO}_{2}$ emissions per year). These achievements would make significant inroads in managing China's energy supply and air pollution problems, and in providing comfortable living space to the people in China. Also, because of the effectiveness of insulation, the use of other heating options, such as electricity or solar energy, become possible.

Table 1. Energy consumed to heat or cool a fiberglass-insulated building and an uninsulated building, for one week of each season.

\begin{tabular}{lcccc}
\hline \multirow{2}{*}{ Building type } & \multicolumn{4}{c}{ Season } \\
\cline { 2 - 5 } & $\begin{array}{c}\text { Autumn } \\
(\mathrm{kW})\end{array}$ & $\begin{array}{c}\text { Winter } \\
(\mathrm{kW})\end{array}$ & $\begin{array}{c}\text { Spring } \\
(\mathrm{kW})\end{array}$ & $\begin{array}{c}\text { Summer } \\
(\mathrm{kW})\end{array}$ \\
\hline Fiberglass-insulated & 90 & 350 & 48 & 100 \\
Uninsulated & 159 & 685 & 100 & 210 \\
\hline
\end{tabular}

From “Insulation Comparison Demonstration" report by B. Justice, Louisiana Department of Natural Resources [6].

\section{Conclusions}

Fiberglass is a common insulation material in Canada and the United States because of its effectiveness, low cost, and user friendliness. A 1-inch thickness of fiberglass (R-value 3.7) is as effective an insulator as a 46inch-thick concrete wall. Good insulation not only helps create comfortable living spaces but it also reduces the need to use air conditioning and heating, which in turn significantly reduces greenhouse gas emissions and air pollution because there is less need to burn coal.

It is important for China to spend more effort on researching and promoting the use of energy-efficient technology and equipment, but it is also important to pay more attention to the benefits of insulating buildings. Insulating existing buildings to the proper standard is a very cost-effective method of saving energy. China can reduce its coal consumption by about 200 million tons each year by introducing the use of fibreglass insulation to urban residential and commercial buildings in regions with severe climates. The $\mathrm{CO}_{2}$ emissions can be reduced by 510 million tons each year, which is about $8.5 \%$ of China's 2006 total carbon emissions.

Although the installation of insulation in buildings requires only a one-time investment on the part of the builder or owner, the positive effects on the environment and the payback are long term. If the broad use of insulation in buildings was introduced today, over the next 50 years China would save a total of 10,000 million tons of coal and reduce $\mathrm{CO}_{2}$ emissions by 25,500 million tons.

Our conclusion is conservative comparing with Dena's report "by applying new standards, the country could cut energy consumption for new buildings by up to 80 percent" [8] because we did not include other factors. Our analysis result is similar to Lei's research "Comparison of Building Codes and Insulation in China and Iceland" [9].

\section{REFERENCES}

[1] World Bank Group, "World Development Indicators, Carbon Dioxide Emissions in Metric Tons per Capita, China,” 2010.

http://www.google.com/publicdata?ds=wb-wdi\&met=en atm_co2e_pc\&idim=country:CHN\&dl=en\&hl=en\&q=car bon+emissions+china

[2] G. Feller, "China's Coal, the Reality of Energy Development in China,” 2010. http://www.ecoworld.com/energy-fuels/chinas-coal.html

[3] K. Bradsher and D. Barboza, "The Energy Challenge: Pollution from Chinese Coal Casts a Global Shadow," 2011.

http://www.nytimes.com/2006/06/11/business/worldbusin ess/11chinacoal.html

[4] D. G. Fridley, N. T. Aden and N. Zhou, "China’s Build- 
ing Energy Use Lawrence Berkeley National Laboratory Report (LBNL-506E),” 2011.

http://china.lbl.gov/publications/chinas-building-energy-u se

[5] EcoWorld, “Air Pollution,” 2010. http://www.ecoworld.com/pollution/air-pollution

[6] B. Justice, J. C. Caldwell, T. M. French and P. Ridgeway, “Insulation Comparison Demonstration,” 2011. http://dnr.louisiana.gov/assets/docs/energy/programs/reside ntial/Zoo_Project_Final_Report.pdf

[7] World Bank Group, “Population 2009: World Development Indicators,” 2010.
http://siteresources.worldbank.org/DATASTATISTICS/R esources/POP.pdf

[8] S. Kohler, "By Applying New Standards, the Country Could Cut Energy Consumption for New Buildings by up to 80 Percent," 2011.

http://www.dena.de/en/services/dena-newsletter/current-is sue/guideli nevalues-for-chinas-building-boom/

[9] H. Lei and P. Valdimarsson, "Comparison of Building Codes and Insulation in China and Iceland," Proceedings of World Geothermal Congress 2010, Bali, 25-29 April 2010. 